\title{
An efficient synthesis towards the core of Crinipellin and Alliacol- $B$ along with their docking studies
}

Raghaba Sahu ${ }^{1, *}$, Ranjan K. Mohapatra ${ }^{2 *}$, Saud I. Al-Resayes ${ }^{3}$, Debadutta Das ${ }^{4}$, Pankaj K. Parhi $^{5}$, Lucia Pintilie ${ }^{6, *}$, Mohammad Azam ${ }^{3 *}$

${ }^{1}$ College of Pharmacy, Seoul National University, Seoul 08826, South Korea.

${ }^{2}$ Department of Chemistry, Government College of Engineering, Keonjhar, Odisha-758002, India.

${ }^{3}$ Department of Chemistry, College of Science, King Saud University, PO Box 2455, Riyadh 11451, Saudi Arabia.

${ }^{4}$ Department of Chemistry, Sukanti Degree College, Subarnapur, Odisha-767017, India.

${ }^{5}$ Department of Chemistry, Fakir Mohan (F.M.) University, VyasaVihar, Nuapadhi, Balasore-756089, Odisha, India.

${ }^{6}$ Department of Synthesis of Bioactive Substances and Pharmaceutical Technologies, National Institute for Chemical \& Pharmaceutical Research and Development, Bucharest, Romania.

*For correspondence-

Dr. RaghabaSahu, E-mail:raghabasahu@gmail.com

Dr. Lucia Pintilie, Email: lucia.pintilie@gmail.com

Dr. Mohammad Azam, Email:azam_res@yahoo.com

Dr. Ranjan K. Mohapatra, Email: ranjank_mohapatra@yahoo.com 


\begin{abstract}
In this present work, we are reporting a novel route for the synthesis of the tetracyclic ring systems, which is a common core of crinipellin via oxidative dearomatization, cycloaddition and oxa- di-pi-methane rearrangement. We considered to exploring a route to tetracyclic core (1e) of Crinipellin and tricyclic core (1g) of Allicaol B through intermolecular diels alder reaction and photochemically 1,2 acyl shift. Moreover, docking study of compound 13 and 16has been investigated against AcrB multidrug efflux pump of Escherichia coli (PDB ID: 1T9U), main protease of SARS COV-2 (PDB ID: 6W63), DNA gyrase of Streptococcus pneumonia (PDB ID: 4Z2C), human estrogen receptor alpha (PDB ID: 3ERT), human lanosterol 14-alpha-demethylase (CYP51) (PDB ID: 3JUS) and cyclooxygenase-2 (Prostaglandin Synthase-2) (PDB ID: 1CX2). The obtained results herein are important for the exploitation of the therapeutic potential of these derivatives as antimicrobial, antiviral, anticancer, antifungal or anti-inflammatory agents.
\end{abstract}

Keywords: Crinipellin; Alliacol-B; cycloaddition; dearomatization; docking study 


\section{Introduction}

The polyquinane natural products have generated a sustained interest among synthetic chemists from the last three decades due to their complex molecular architecture and wideranging biological properties. ${ }^{1 \mathrm{a}-\mathrm{d}}$ In 1979, the research group of Anke and Steglich reported the isolation of an antibiotic crinipellin A 1a from the submerged cultures of basidomycete Crinipellisstipitaria, strain 7612, which was found to be most active against Gram-positive bacteria. ${ }^{2}$ Afterward, Steglich and co-workers have isolated some more crinipellins $\mathbf{1 b}$, $\mathbf{1}$ cand 1d(Figure 1). By further investigations on several strains of C. Stipitaria, which were found to exhibit antibiotic activity. ${ }^{3}$ Crinipellins, are the first group of polyquinane diterpenoids to contain a tetraquinane framework which integrates together a linear cis:anti:cistriquinane along with angular triquinane ring systems. Hanson and Thallerl have reported a novel sesquiterpenealliacolide, from cultures of the basidiomycete Marasmius alliaceus. ${ }^{4}$ These substrates show adequate antimicrobial activity and inhibit DNA synthesis in the ascetic form of Ehrlich carcinoma at concentrations less than $10 \mu \mathrm{g} / \mathrm{mL} .^{2}$

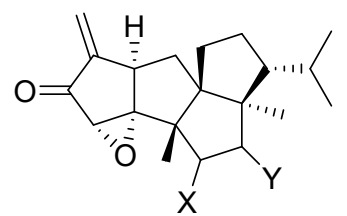

1a $X=O, Y=\alpha O H$ (crinipellin $A$ ) 1b $X=\beta O H, Y=O$ (crinipellin $B$ )

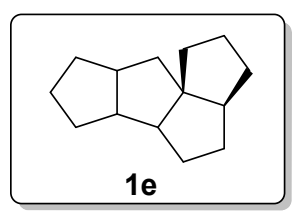

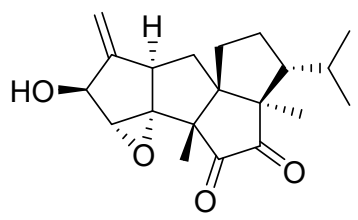

1c (crinipellin C)

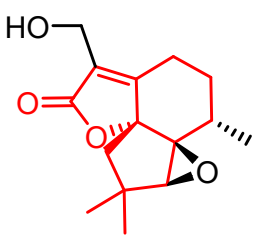

1f (Alliacol B)

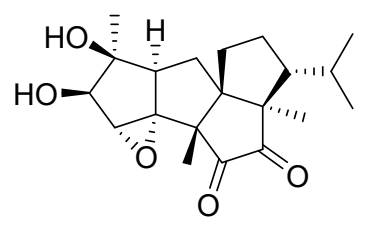

1d (crinipellin $D$ )

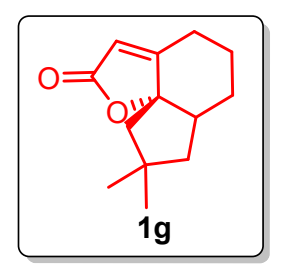

Figure 1

Studies towards synthesis of architecturally more complex crinipellinsare limitedand there are only a few total syntheses of crinipellin B. ${ }^{5}$ Recently, a total synthesis of crinipellin A has reported by Lee and co-workers. ${ }^{6}$ Singh et. Al have been interested in the creation of new 
approach for creating molecular complexity by engaging oxidative dearomatization of $o$ hydroxymethyl phenols, cycloaddition, and photochemical reactions. ${ }^{7}$ Taking into consideration of interest towards crinipellin1, as well as alliacol B2, we extended our previous approach towards angular triquinane ${ }^{8}$ to tetraquinane and alliacol B. Herein, we wish to report a novel route for the synthesis of the tetracyclic ring systems $\mathbf{1 e}$, which is a common core of crinipellin via oxidative dearomatization, cycloaddition and oxa-di-pimethane rearrangement.

We considered to exploring a route to tetraquinane1e which is core of Crinipellin through intermolecular diels alder reaction and photochemically 1,2 acyl shift (Scheme 1). It was contemplated that the angularly fused tetraquinane of type 1emay beobtained from compound 6 by cyclopropane ring cleavage followed by hydrogenation.
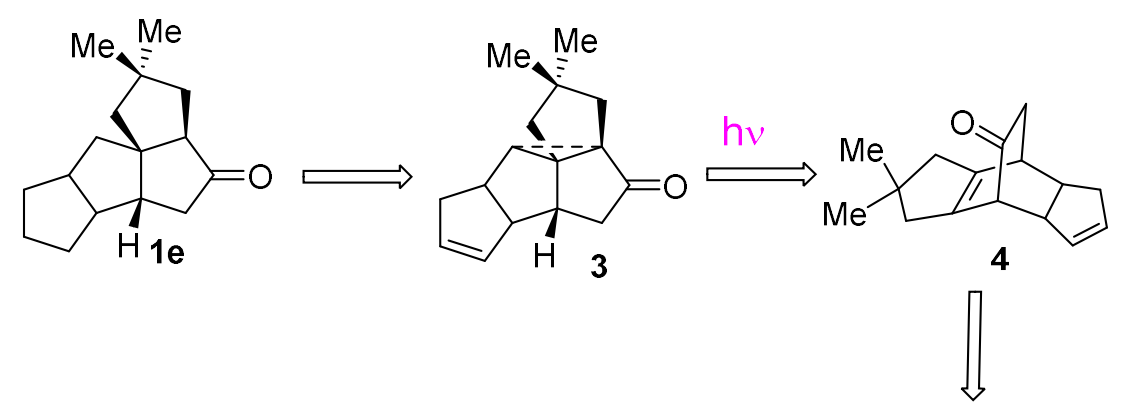

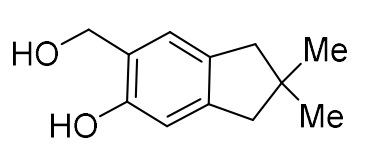

6

\section{Scheme 1}

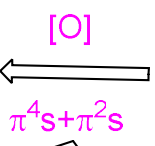

10

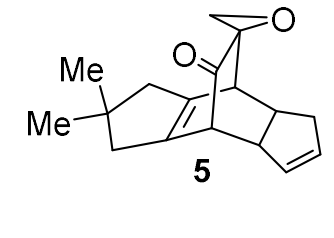

The tetracyclic compound 3 was appeared accessible via 1,2-acyl shift (oxa-di- $\square$-methane rearrangement) in the tricyclic compound $\mathbf{4}$ endowed with a $\beta$ - $\gamma$-enonechromophoric system. We envisioned that the key precursor 4would be obtained from keto epoxide $\mathbf{5}$ by manipulation of oxirane ring. The tricyclic keto epoxides 5 wasconsidered to be prepared from aromatic precursor $\mathbf{1 0}$ via oxidative dearomatization to spiroepxycyclohexa-2-,4dienone 9 followed by cycloaddition with dienophilecyclopentadiene. The aromatic precursors 6 would be readily prepared from 5-methoxy indanone. ${ }^{8}$ 
As we all know that the ongoing COVID-19 outbreak driven by highly infectious SARSCoV-2 and causing the current pandemic and has turned on the most critical universal health disaster of this century $[9,10]$. So, after synthesizing the compounds, we have performed the molecular docking studies against some selected proteins/enzymes receptors by using CLC Drug Discovery Workbench Software.

\section{Result and discussion}

In continuation of our theme towards synthesis of angular triquinanes, we had also thought of exploring a synthetic route to angular tetraquinanes along the similar lines as presented earlier. The tetracyclic chromophoric system 4 was readily synthesized from the aromatic precursor $\mathbf{6}$ as described below. Interestingly, oxidative dearomatization of $\mathbf{6}$ in the presence of cyclopentadiene directly gave the adduct $\mathbf{5}$ in reasonably good yield along with some unreacted spiroepoxycyclohexa-2,5-dienone 9 (Scheme 2). This is presumably due to high reactivity of cyclopentadiene which could intercept the cyclohexadienone 9 formed in situ even under ambient conditions. The structure of adduct $\mathbf{5}$ was confirmed from its spectral features.

Further, it may be worth noting that adduct $\mathbf{5}$ is formed in a highly regio- and stereoselectivecycloaddition wherein the cyclohexadienone behaves as $4 \square$-partner and cyclopentadiene as a $2 \square$-partner (dienophile) and that other products arising from alternate pericyclic modes [such as $\square^{4} \mathrm{~s}($ cyclopentadiene $)+\square^{2} \mathrm{~s}$ (cyclohexadienone)] was not formed.

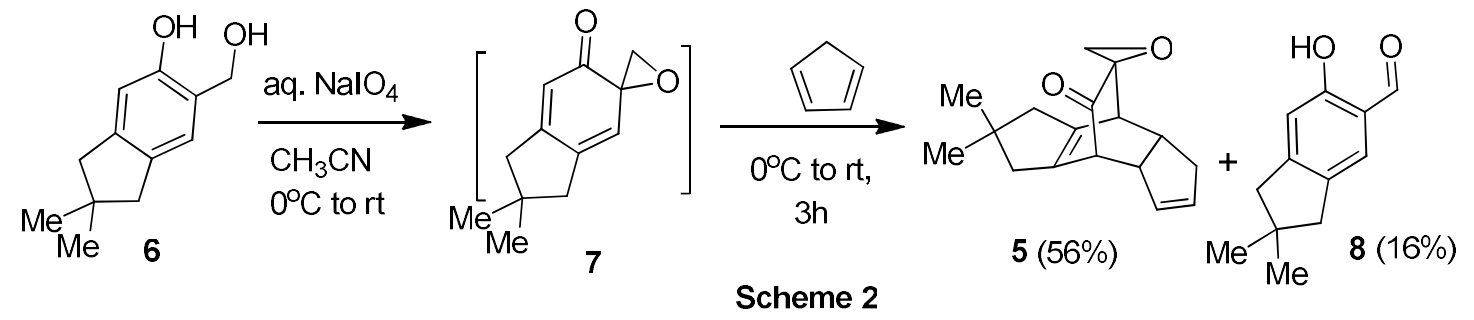

The adduct 5 was converted into the desired chromophoric system $\mathbf{4}$ as shown in Scheme 3. Thus, the keto-epoxide 5 was reduced with activated zinc in aqueous methanol (protic solvent) in the presence of ammonium chloride which gave the keto-alcohol $\mathbf{1 0}$ asthe major product 
(mixture of syn-anti isomers) along with ketone $\mathbf{9}$ as a minor product. Oxidation of the keto alcohol 10 with Jones reagent followed by decarboxylation of the resulting $\beta$-keto-acid furnished the desired tricyclic compound $\mathbf{4}$ endowed with a $\beta, \gamma$-enonechromophore in good yield. The structures of all the compounds were supported from their spectral features.

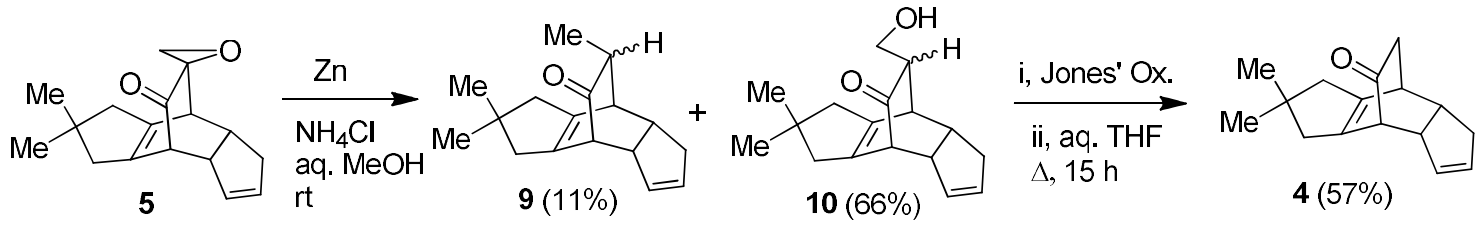

Scheme 3

After having obtained the tetracyclic compound 4, it was subjected to sensitized irradiation in acetone. Chromatography of the photolysate gave both products, the compound $\mathbf{1 1}$ containing cyclobutanone ring formed due to 1,3-acyl shift and pentacyclic compound $\mathbf{1 2}$ (formed due to oxa-di- $\pi$-methane rearrangement) in almost equal yields (Scheme 4).
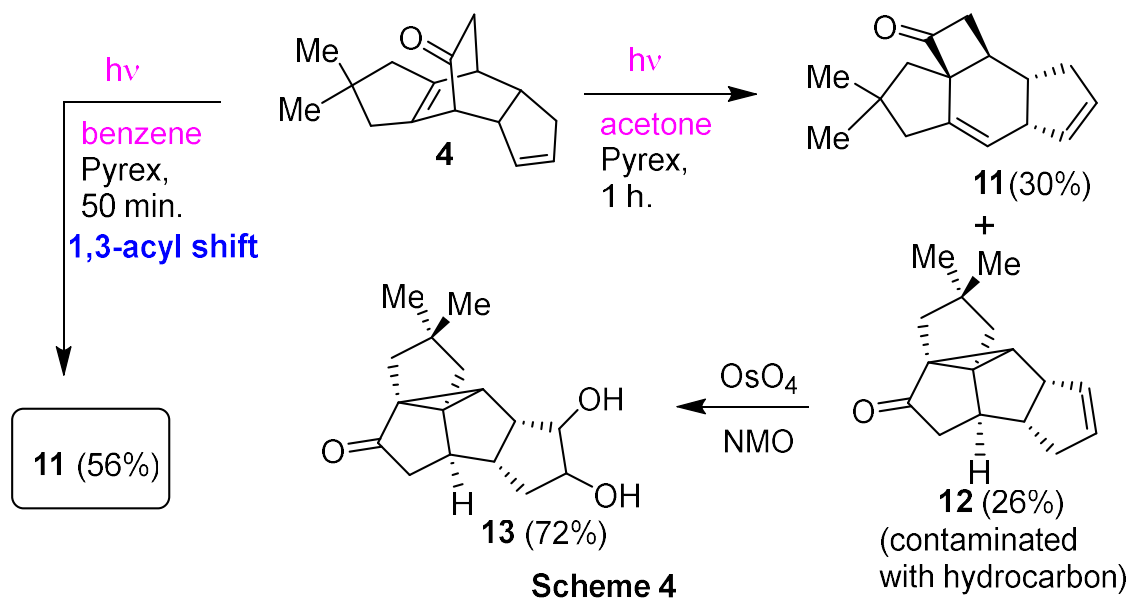

The ${ }^{1} \mathrm{H}$ NMR and ${ }^{13} \mathrm{C}$ NMR spectra of the more nonpolar product 12 indicated that it is contaminated with some inseparable hydrocarbon (which could not be separated even after repeated column chromatography). Therefore, the product 12 was subjected to dihydroxylation with $\mathrm{OsO}_{4}$ which gave the pentacyclicdiol13 (Scheme 3.14) in excellent yield as a single diastereoisomer $\left({ }^{1} \mathrm{H}\right.$ NMR and ${ }^{13} \mathrm{C}$ NMR spectra) whose structure was fully corroborated with its spectral characteristics. However, stereochemical orientation of the hydroxyl groups was not easily discernible from spectral features.

The behaviour of tetracyclic compound 4is same with previous tricyclic chromophoric systems 14 under photochemical transformation. ${ }^{8} \mathrm{As}$, the 1,3-acyl shift product $\mathbf{1 5}$ was 
formed as a major amount in both direct irradiation as well as sensitized irradiationof compound 14, It was converted to its tricyclic lactone $\mathbf{1 6}$ which is a core ofAlliacol B. The lactonisationwas done by Bayer-Villiger reaction by treating with $\mathrm{m}-\mathrm{CPBA}$ in the presence of $\mathrm{NaHCO}_{3}($ Scheme 5) and leads tosingle regioisomer16.

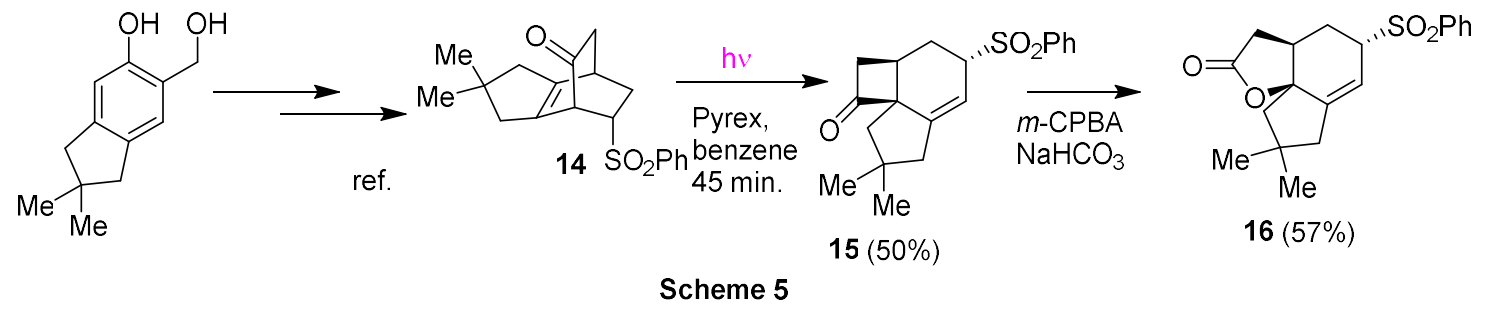

\section{Molecular docking study}

Molecular docking study, using CLC Drug Discovery Workbench Software [11], was effectuated on two ligands to obtained accurate predictions about structure and interactions of the studied compounds in complex with a protein/enzyme receptor in order to evaluate the biological activity. We have used some proteins/enzymes receptors who was imported from protein data bank (http://www.rcsb.org/:PDB), AcrB multidrug efflux pump of Escherichia coli (PDB ID: 1T9U [12]), main protease of SARS COV-2 (PDB ID: 6W63[13]), DNA gyraseof Streptococcus pneumonia (PDB ID: 4Z2C[14]), human estrogen receptor alpha (PDB ID: 3ERT[15]), human lanosterol 14-alpha-demethylase (CYP51)(PDB ID: 3JUS[16]) and cyclooxygenase-2 (Prostaglandin Synthase-2) (PDB ID: 1CX2[17].

In the docking simulation, the ligands (compounds 13 and 16) (Figure 1) are placed into apredictable binding site on the surface of a protein target. CLC Drug Discovery Workbench utilizes also MMFF94 (MMFF) force field when generate 3D structure on import. Different conformations are generated by rotation about rotatable bonds and conformation changes. Thus, the ligand optimizer was realized by geometry minimization using MMFF94 force field. Also, the minimization of the ligand is conforming to the binding pocket geometry.The protein-ligand interaction is scored, and the best scoring binding mode is returned for individually ligand, collected with the score. The ligand binding mode search 
is effectuated inside in the binding site (green sphere with a radius large enough to comprise all ligands docked to the receptor protein). After the import of the protein receptor from PDB bank, the next step is the setup binding site and the setup binding pockets; binding pockets are necessary to guide the docking simulation. After the setup the binding site and the binding pocket, the co-crystallized- natural ligand was extracted and was redocking in the active binding site of the protein receptor, for the validation of the method and of the docking parameters obtained from the molecular docking studies.

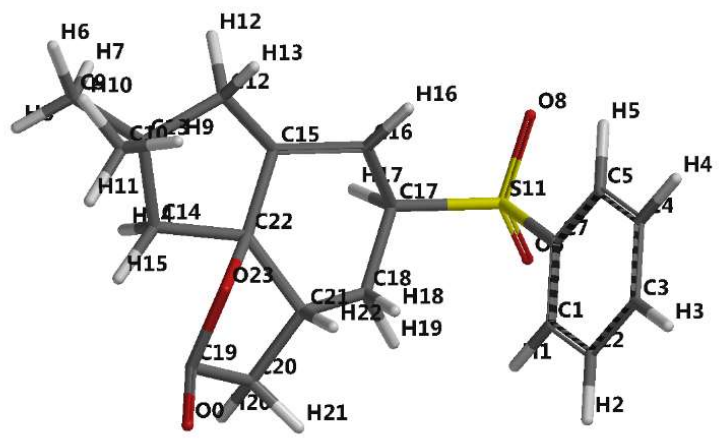

Compound 16

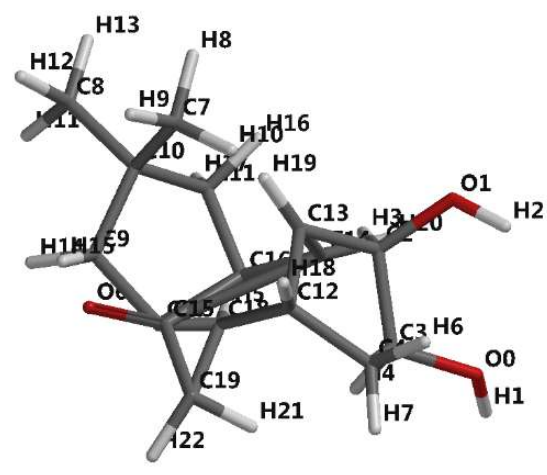

Compound 13

Figure 1. Tube representation of the optimized molecular structure of compounds $\mathbf{2 0}$ and $\mathbf{3 3}$ (Numbering of the atoms was done according to the software)

\section{Docking evaluation against AcrB multidrug efflux pump of Escherichia coli}

Docking studies was realized to achieve accurate predictions on the optimized conformations for both the ligands and protein target to form a stable complex. The two compounds was docked on the crystal structure of AcrB multidrug efflux pump of Escherichia coli (PDB ID: 1T9U). The docking pose of the co-crystallized ciprofloxacin interacting with amino acid residues of the active site and the hydrogen bonds created with ARG 468 (three bonds: 3.129 $\AA, 3.062 \AA$ and $3.073 \AA$ ) are shown in Figure S1a. The ciprofloxacin was taken as reference ligand to compare the docking results of the two studied compounds. The docking studies revealed that the docking score of the two compounds 16 and 13 are smaller than docking score of co-crystallized (docking score: -46.33 ; RMSD: $0.67 \AA$ ). The compound 16, has a 
docking score: -46.33 (RMSD: $0.67 \AA$ ) and shows occurence of three hydrogen bonds, onewith GLN 469 (2.631 $\AA$ ) and two with ARG 468 (2.620 ̊ and $3.112 \AA$ ) (Figure 2a). The compound 13 showed occurence of six hydrogen bonds with ARG 468 (2.884 Å), ASN 391

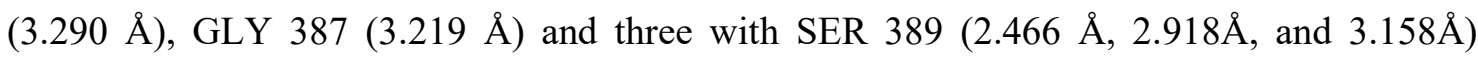
(Figure S2a). The docking pose of the co-crystallized CPX and of the compounds $\mathbf{2 0}$ and $\mathbf{3 3}$ interacting with the amino acids residues is presented in Figure $S 1 b, 2 b$ and $S 2 b$. The amino acids residues that formed the interacting group of each ligand are listed in Table S1. After analyzing the data obtained from the docking study, it was observed that the two studied compounds were placed in the same binding site of 1T9U as the cocrystallized one (Figure 2c).
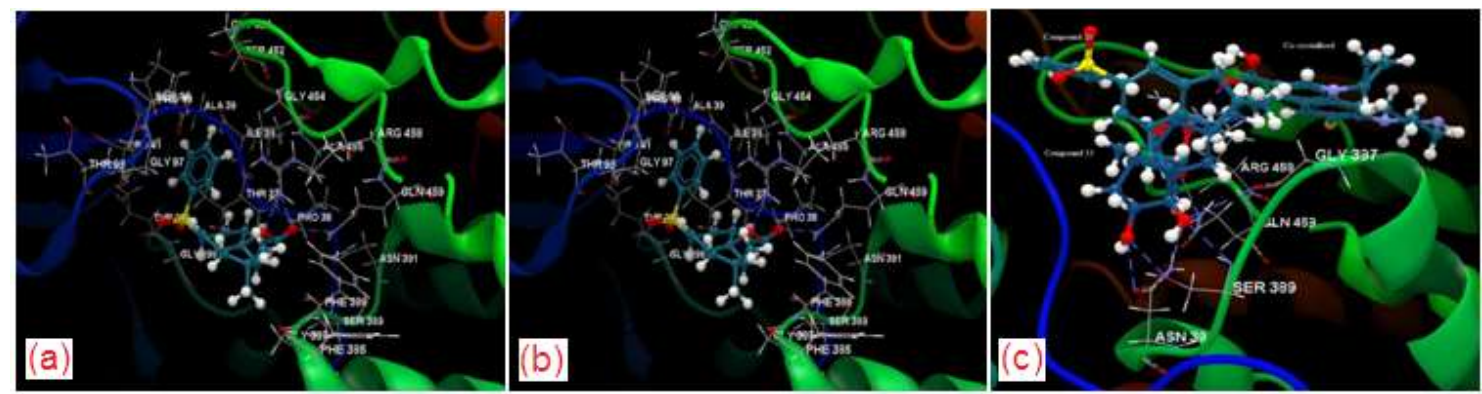

Figure 2. (a) Hydrogen bonds (blue dotted lines) between Compound 20 and ARG 468 GLN 469 amino acids, (b)Docking pose of the compound 20interacting with the amino acid residues of binding site of 1T9U, (c) Docking pose of the co-crystallized CPX and of compounds $\mathbf{2 0}$ and $\mathbf{3 3}$ in the binding site of 1T9U.

\section{Docking evaluation against Main protease of SARS-CoV-2}

Docking studies was realized to achieve accurate predictions on the optimized conformations for both the ligands and protein target to form a stable complex. The two compounds was docked on the crystal structure of Main protease of SARS-CoV-2 (PDB ID: 6W63). The docking pose of the co-crystallized X77 interacting with amino acid residues of the active site and the hydrogen bonds created with GLU 166 (2.721 $\AA$ )and GLY 143(3.202 $)$ are shown in Figure S3a. The co-crystallized X77 (N-(4-tert-butylphenyl)-N-[(1R)-2-(cyclohexylamino)-2- 
oxo-1-(pyridin-3-yl)ethyl]-1H-imidazole-4-carboxamide) was taken as reference ligand to compare the docking results of the compounds16 and 13. The docking studies revealed that the docking score of the compound 16(docking score: -56.15; RMSD: $0.11 \AA$ ) is close to that of the co-crystallized (docking score: -56.57 ; RMSD: $1.53 \AA$ ), but these compound do not realize hydrogen bonds with the amino acids from the active site of the protein receptor (Figure 3a). Compound 33 shows occurence of two hydrogenbonds with TYR 54 (2.765 ) and ASP 187 (2.752 $\AA$ ) (Figure S4a). The docking pose of the co-crystallized and of the compounds 16 and 13, interacting with the amino acids residues is presented in Figure S3b, $3 \mathrm{~b}$ and $\mathrm{S} 4 \mathrm{~b}$. The amino acids residues who formed the interacting group of each ligand are listed in Table S2. After analyzing the data obtained from the docking study, it was observed that the two studied compounds were placed in the same binding site of 1T9U as the cocrystallized one (Figure 3c).
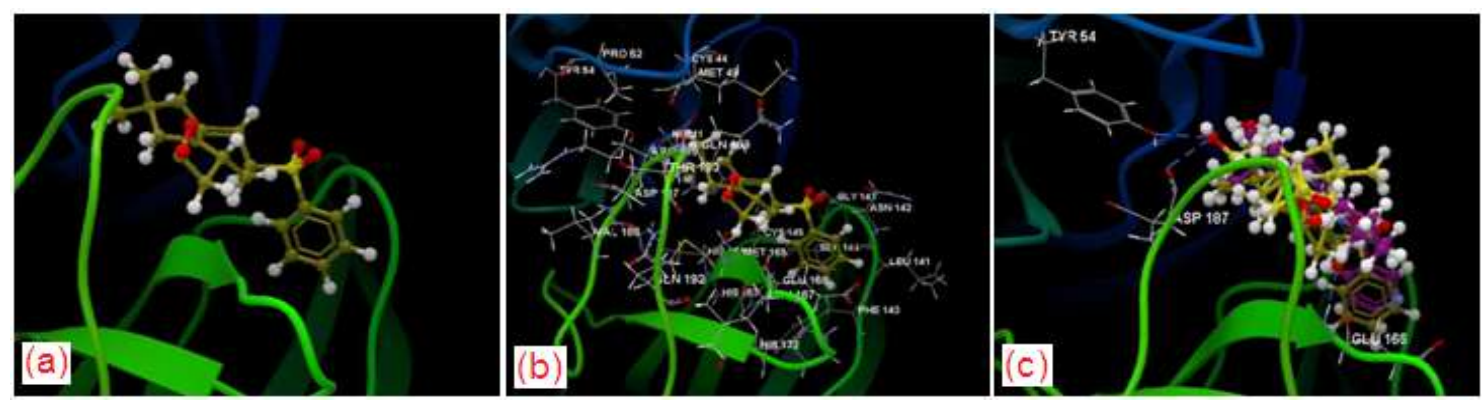

Figure 3. (a)Doching pose of compound 20, (b) Docking pose of the compound 20 interacting with the amino acid residues of binding site of 6W63, (c) Docking pose of the cocrystallized (purple) and compound $\mathbf{2 0}$ (olive) and $\mathbf{3 3}$ (yellow) in the binding site of 6W63.

\section{Docking evaluation against Streptococcus pneumoniae DNA gyrase}

Docking studies was realized to achieve accurate predictions on the optimized conformations for both the ligands and protein target to form a stable complex. The two compounds was docked on the crystal structure of Streptococcus pneumonia DNA gyrase(PDB ID:4Z2C). The docking pose of the co-crystallized, moxifloxacin, (MFX) interacting with amino acid residues and nucleotids of the active site and the hydrogen bonds created with SER 436:D 
$(2.953 \AA, 3.030 \AA, 2.597 \AA), \mathrm{DG} 1: \mathrm{H}(3.099 \AA)$ and DA $2: \mathrm{H}(3.112 \AA)$ are shown in Figure S5a. The co-crystallized MFX was taken as reference ligand to compare the docking results of the compounds $\mathbf{1 6}$ and 13. The docking studies revealed that the docking score of the two compounds 16and 13 are smaller than docking score of co-crystallized (docking score: 83.33; RMSD: $1.53 \AA$ ). The compound 16, has a docking score: -63.48 (RMSD: $0.04 \AA$ ) and showed occurence of two hydrogen bonds, one with GLY 457:D (3.096 ^) and with DG 1:H $(2.898 \AA)$ (Figure 4a). The compound 13 showed occurence of four hydrogen bonds with ARG 456:D (3.084 $\AA)$, GLU 475:D (2.791 $\AA$ ), and two with DA 5:F (3.015 $\AA, 3.133 \AA)$ (Figure S6a). The docking pose of the co-crystallized and of the compounds $\mathbf{1 6}$ and $\mathbf{1 3}$ interacting with the amino acids residues is presented in Figure S5b, $4 \mathrm{~b}$ and S6b. The amino acids residues that formed the interacting group of each ligand are listed in Table S3. After analyzing the data obtained from the docking study, it was observed that the two studied compounds were placed in the same binding site of $4 \mathrm{Z} 2 \mathrm{C}$ as the cocrystallized one (Figure $4 \mathrm{c})$.
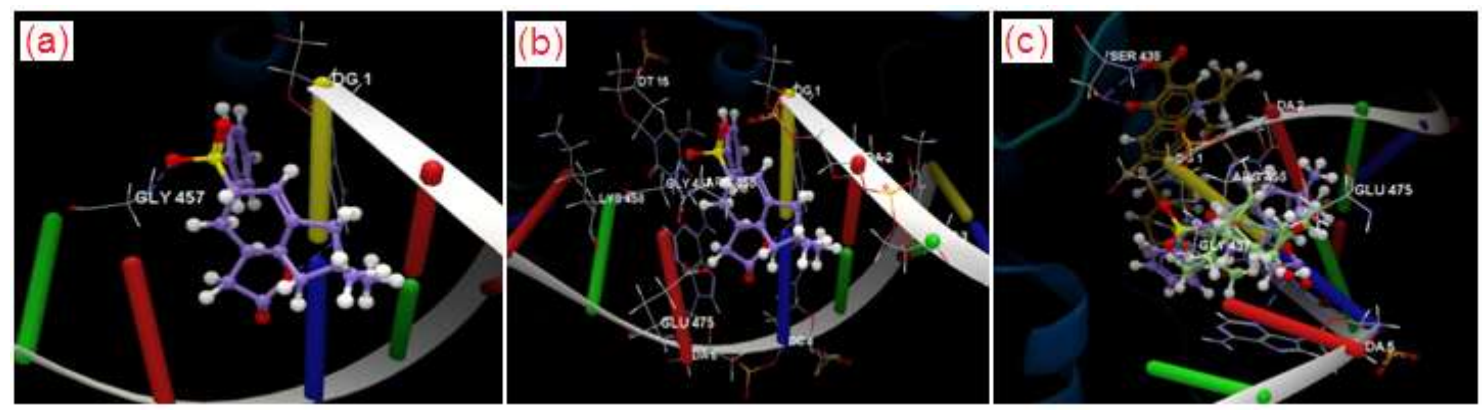

Figure 4. (a) Hydrogen bonds (blue dotted lines) between compound 20 and GLY 457(D) amino acid and DG1(H) nucleotid, (b)Docking pose of the compound 20 interacting with the amino acid residues and nucleotids of binding site of 4Z2C, (c)Docking pose of the cocrystallized (brown) and compound 20(violet) and 33(light green)in the binding site of $4 \mathrm{Z} 2 \mathrm{C}$.

\section{Docking evaluation against Human estrogen receptor alpha}

Docking studies was realized to achieve accurate predictions on the optimized conformations for both the ligands and protein target to form a stable complex. The two compounds was 
docked on the crystal structure of Human estrogen receptor alpha (PDB ID:3ERT).The docking pose of the co-crystallized OHT (4-hydroxytamoxifen) interacting with amino acid residues of the active site and the hydrogen bonds created with GLU 353 (2.998 $\AA$ ) and ARG 394 (2.397 $\AA)$ are shown in Figure S7a. The co-crystallized OHT was taken as reference ligand to compare the docking results of the compounds $\mathbf{1 6}$ and $\mathbf{1 3}$. The docking studies revealed that the docking score of the two compounds 16 and $\mathbf{1 3}$ are smaller than docking score of co-crystallized (docking score: -76,36; RMSD: $0.68 \AA$ ). The compound 16, has a docking score: -54.09 (RMSD: 0.03 $)$ ) and showed occurence of one hydrogen bond with THR 347 (2.742 $\AA$ ) (Figure 5a). The compound 13 showed occurence of five hydrogen bonds

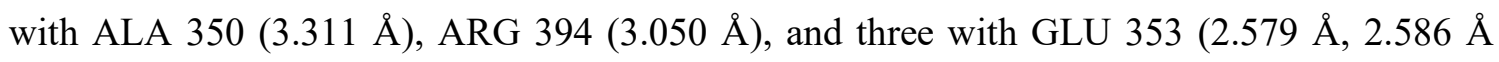
and $3.386 \AA$ ) (Figure S8a). The docking pose of the co-crystallized and of the compounds $\mathbf{1 6}$ and 13 interacting with the amino acids residues is presented in Figure S7b, 5b and S8b. The amino acids residues that formed the interacting group of each ligand are listed in Table S4. After analyzing the data obtained from the docking study, it was observed that the two studied compounds were placed in the same binding site of 3ERT as the cocrystallized one (Figure $5 \mathrm{c})$.
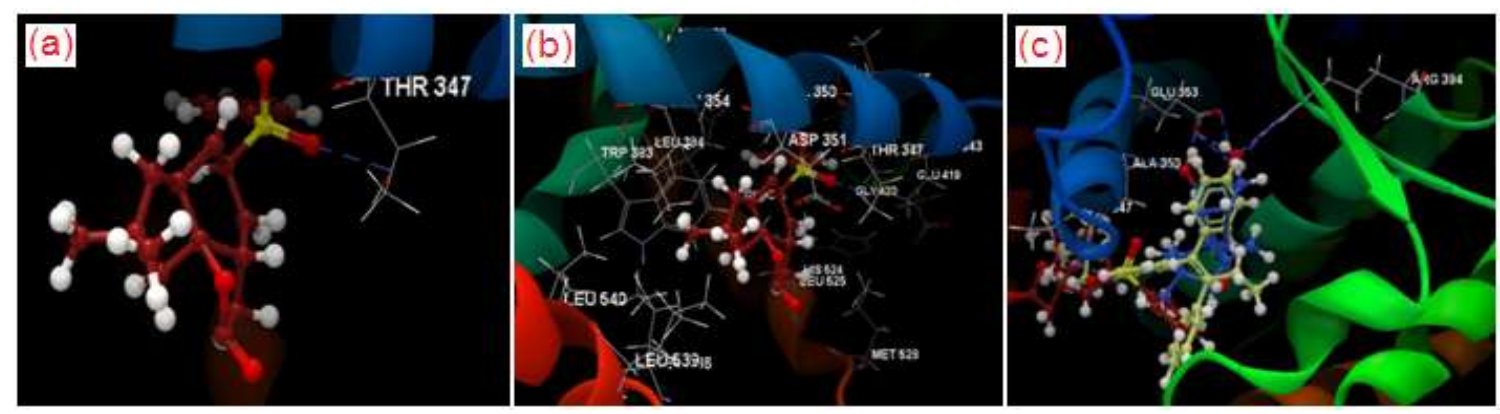

Figure 5. (a) Hydrogen bonds (blue dotted lines) between compound 16and THR 347 amino acid, (b)Docking pose of the compound 16interacting with the amino acid residues of binding site of 3ERT, (c)Docking pose of the co-crystallized (yelow) and compound 16(red) and 13 (blue) in the binding site of 3ERT. 


\section{Docking evaluation against Human lanosterol 14-alpha-demethylase (CYP51)}

Docking studies was realized to achieve accurate predictions on the optimized conformations for both the ligands and protein target to form a stable complex. The two compounds was docked on the crystal structure of human lanosterol 14alpha-demethylase (CYP51) (PDB ID:3JUS). The docking pose of the co-crystallized ECN (1-[(2S)-2-[(4-chlorobenzyl)oxy]-2(2,4-dichlorophenyl)ethyl]-1H-imidazole) interacting with amino acid residues of the active site and the hydrogen bond created with TYR 145 (3.103 $\AA)$ are shown in Figure S9a. The co-crystallized OHT was taken as reference ligand to compare the docking results of the compounds 16 and 13. The docking studies revealed that the docking score of the two compounds 16and 13 are smaller than docking score of co-crystallized (docking score: -

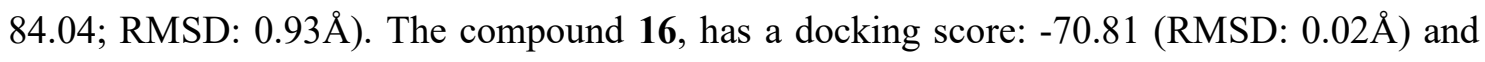
showed occurence of one hydrogen bonds TYR 145 (2.983 $\AA$ ) (Figure 6a). The docking studies revealed that the docking score of the compound 13 is -56.78 , (RMSD: $0.02 \AA$ ) but this compound does not realize hydrogen bonds with the amino acids from the active site of the protein receptor (Figure S10a). The docking pose of the co-crystallized and of the compounds $\mathbf{1 6}$ and $\mathbf{1 3}$ interacting with the amino acids residues is presented in Figure S9b, 6b and $\mathrm{S} 10 \mathrm{~b}$. The amino acids residues that formed the interacting group of each ligand are listed in Table S5. After analyzing the data obtained from the docking study, it was observed that the two studied compounds were placed in the same binding site of 3ERT as the cocrystallized one (Figure 6c). 

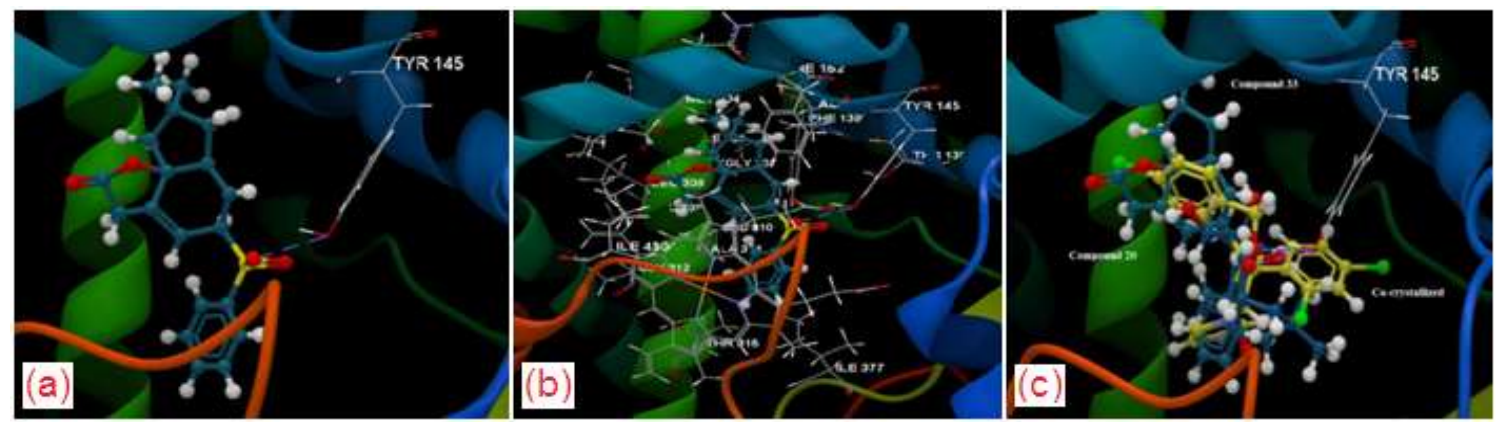

Figure 6. (a) Hydrogen bonds (blue dotted lines) between compound 16and TYR 145 amino acid, (b)Docking pose of the compound 16interacting with the amino acid residues of binding site of 3JUS, (c)Docking pose of the co-crystallized and compound 16and 13 in the binding site of $3 J U S$.

\section{Docking evaluation against Cyclooxygenase-2 (Prostaglandin Synthase-2)}

Docking studies was realized to achieve accurate predictions on the optimized conformations for both the ligands and protein target to form a stable complex. The two compounds was docked on the crystal structure of Human lanosterol 14-alpha-demethylase (CYP51) (PDB ID: 1CX2). The docking pose of the co-crystallized S58 (1-phenylsulfonamide-3trifluoromethyl-5-para bromophenylpyrazole) interacting with amino acid residues of the active site and the hydrogen bonds created with HIS 90 (2.894 $\AA$ and $3.144 \AA$ ), ARG 513 (3.035 $\AA$ ) and SER 353 (2.534 $\AA$ ) are shown in Figure S11a. The co-crystallized OHT was taken as reference ligand to compare the docking results of the compounds $\mathbf{1 6}$ and $\mathbf{1 3}$. The docking studies revealed that the docking score of the two compounds $\mathbf{1 6}$ and $\mathbf{1 3}$ are smaller

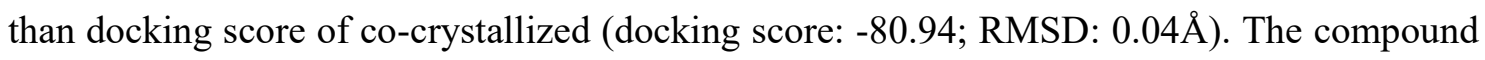
16, has a docking score: -71.73 (RMSD: $0.04 \AA$ ) and showed occurence of three hydrogen bonds, one with SER $530(2.876 \AA$ ) and two with TYR 385 (2.882 $\AA$ and $3.091 \mathrm{~V} \AA$ ) (Figure 7a). The compound 33 showed occurence of one hydrogen bond with TYR 355 (2.872 $\AA$ ). (Figure S12a). The docking pose of the co-crystallized and of the compounds $\mathbf{1 6}$ and $\mathbf{1 3}$ interacting with the amino acids residues is presented in Figure S11b, $7 \mathrm{~b}$ and S12b. The amino acids residues that formed the interacting group of each ligand are listed in Table S6. After analyzing the data obtained from the docking study, it was observed that the two 
studied compounds were placed in the same binding site of 3ERT as the cocrystallized one (Figure 7c).
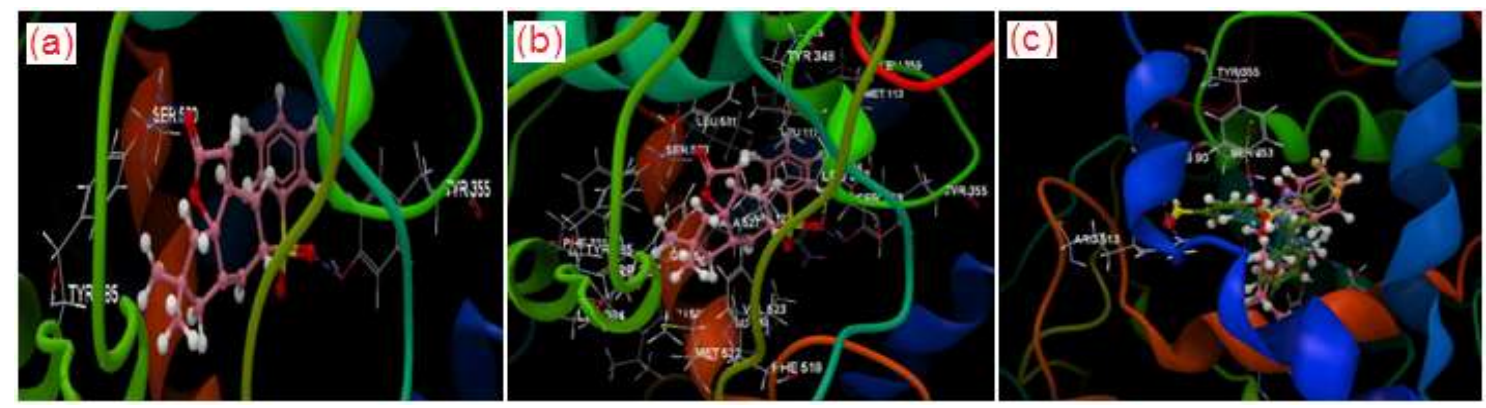

Figure 7.(a) Hydrogen bonds (blue dotted lines) between compound 16and SER 539, TYR 385 and TYR 355 amino acids, (b)Docking pose of the compound 20 interacting with the amino acid residues of binding site of 1CX2, (c)Docking pose of the co-crystallized (green) and compound 16(pink) and $\mathbf{1 3}$ (ocean blue) in the binding site of $1 \mathrm{CX} 2$.

It has been calculated the parameters who can predict if a molecule possesses properties that might turn it into an active drug, according to the Lipinski's rule of five [18], the number of hydrogen donors $<5$ ), the number of acceptors hydrogen $<10$ ), molecular weight $<500 \mathrm{Da}$, the octanol-water partition coefficient $(\log P)<5$. (Table 1$)$. The number of violations of the Lipinski rules allows to evaluate drug likeness for a molecule. It was observed that compounds 20 and 33 have zero violation of all the parameters involved in Lipinski's rule of five (Lipinski violation is 0 ).

Table 1. Calculated properties of compounds

\begin{tabular}{|c|c|c|c|c|c|c|c|}
\hline Compounds & $\frac{\mathscr{a}}{\stackrel{\Xi}{z}}$ & 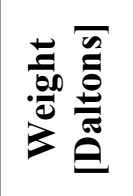 & $\begin{array}{ll}\frac{0}{0} & 0 \\
\frac{\pi}{2} & 0 \\
\frac{0}{x} & 0\end{array}$ & 氧 & 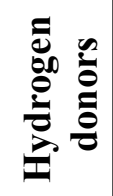 & 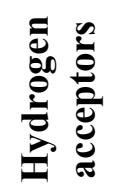 & $\log P$ \\
\hline Co-crystallized ${ }^{*} \mathbf{C p}$ & 42 & 331.34 & 3 & 0 & 2 & 6 & 0.84 \\
\hline Co-crystallized ${ }^{* *} \mathbf{X 7 7}$ & 66 & 458.58 & 7 & 0 & 1 & 7 & 4.59 \\
\hline Co-crystallized $^{* * *} \mathbf{M X F}$ & 53 & 401.43 & 4 & 0 & 2 & 7 & 1.62 \\
\hline Co-crystallized ${ }^{* * * *}$ OHT & 58 & 387.51 & 8 & 1 & 1 & 3 & 6.78 \\
\hline Co-crystallized ${ }^{* * * * *} \mathbf{E C N}$ & 39 & 381.68 & 6 & 0 & 0 & 3 & 4.70 \\
\hline Co-crystallized ${ }^{* * * * * *} \mathbf{S 5 8}$ & 37 & 446.24 & 4 & 0 & 2 & 5 & 3.65 \\
\hline Compound $\mathbf{2 0}$ & 46 & 346.44 & 2 & 0 & 0 & 4 & $\begin{array}{c}2.10^{*} / 2.75^{* *} / 2.62^{* * * *} / 1 \\
97^{* * * * *} \\
2.22^{* * * * *} / 2.62^{* * * * * *} \\
\end{array}$ \\
\hline Compound $\mathbf{3 3}$ & 41 & 262.34 & 0 & 0 & 2 & 3 & 0.99 \\
\hline
\end{tabular}


After analyzing the results of the molecular docking study, it is observed that the two compounds 16 and 13 possess properties that can turn them into future oral drugs (Lipinski violation is 0 ) (Table 1). It was also found that compound $\mathbf{1 6}$ could be a drug with antimicrobial, antiviral, anticancer, antifungal or anti-inflammatory activity. For all molecular docking studies against the studied targets, it was also observed that compound $\mathbf{1 6}$ has a higher docking score than compound $\mathbf{1 3}$ and is close to each co-crystallized ligand taken as reference (Figure 8).

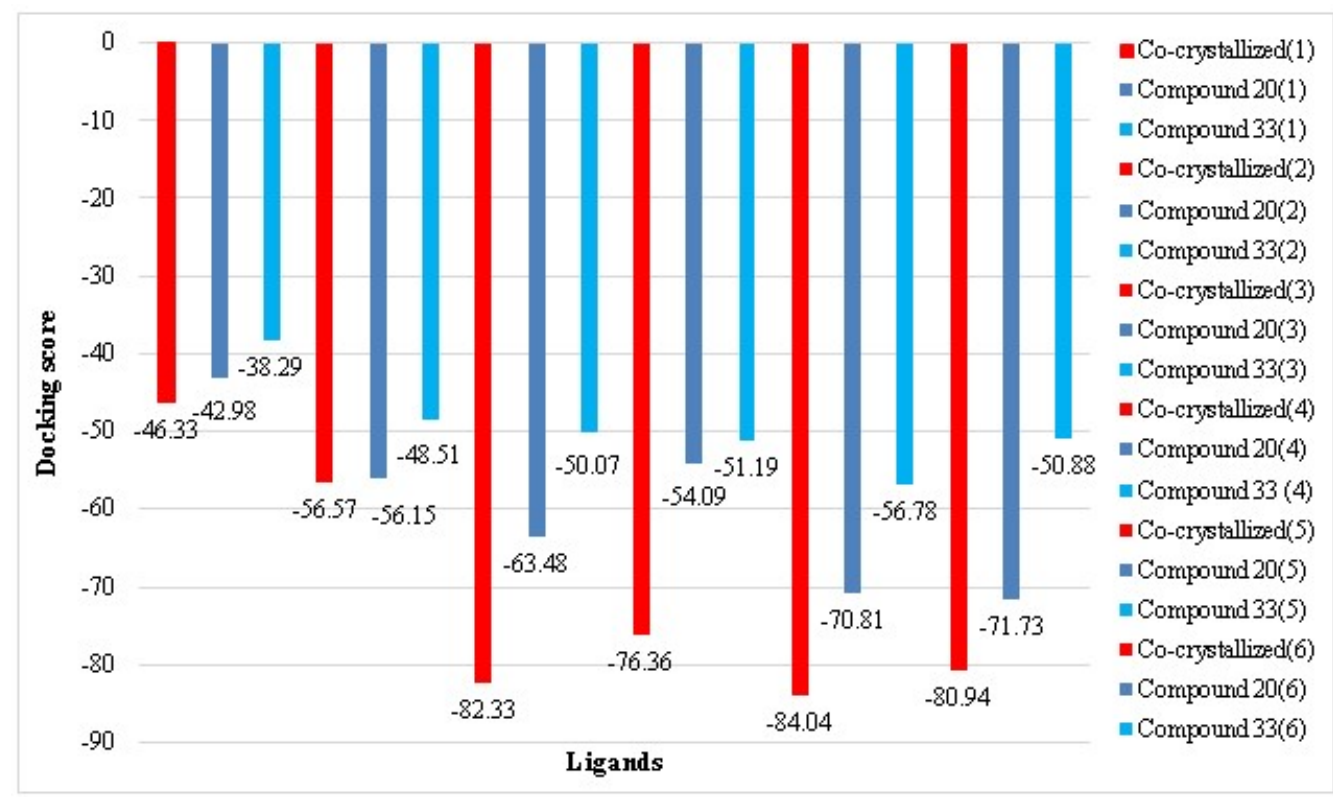

(1)PDB ID: 1T9U; (2) PDB ID: 6W63; (3)PDB ID: 4ZDC; (4)PDB ID: 3ERT; (5) PDB ID: 3JUS; (6)PDB ID: 1CX2

Figure 8. Docking scores of ligands

\section{Conclusion}

In summary, we have described a facile route to complex molecular skeleton of crinipellin from simple aromatic compound through a short and efficient synthetic route. The sensitized irradiation of 4 led to oxa-di- $\square$-methane reaction only to a moderate extent thus limiting its synthetic application. Nevertheless, the present study provides additional examples of photoreaction of rigid $\square \square \square$-enones and demonstrates the effect of structure on the photoreactivity, and provides novel carbocyclic systems that are not readily accessible 
otherwise. Moreover, from molecular docking study, it is observed that compounds $\mathbf{1 6}$ and $\mathbf{1 3}$ possess properties that can turn them into future oral drugs. It was also found that compound 16 could be a drug with antimicrobial, antiviral, anticancer, antifungal or anti-inflammatory activity. In addition, compound $\mathbf{1 6}$ has a higher docking score than compound $\mathbf{1 3}$ and is close to each co-crystallized ligand taken as reference.

\section{Experimental section}

\section{Physical measurements}

All the glassware was oven dried and chemicals are commercially available from sigma aldric and, merch and TCI otherwise it is mentioned if prepared. ${ }^{1} \mathrm{H}$ NMR and ${ }^{13} \mathrm{C}$ NMR spectra were recorded on Bruker $400 \mathrm{MHz}$ and $500 \mathrm{MHz}$ instruments. Samples were dissolved in $\mathrm{CDCl}_{3}$ containing TMS as internal standard. IR spectra were recorded on PerkinElmer FT-IR instrument. High-resolution mass spectra were recorded on Maxis impact Bruker mass spectrometer. Melting points were recorded on Buchi M-560 instrument. Reactions were monitored by thin layer chromatography (TLC) using silica gel and spots were visualized with iodine vapour. Column chromatography was performed on silica gel for chromatography (100-200 mesh).

\section{2,2-Dimethyl-1,2,3,4,4a,5,7a,8-octahydrospiro[4,8-ethano-s-indacene-10,2'-oxiran]-9-one}

To a solution of phenol $\mathbf{6}(1.0 \mathrm{~g}, 5.2 \mathrm{mmol})$ in acetonitrile $(25 \mathrm{~mL})$, was added freshly cracked cyclopentadiene $\left(5 \mathrm{~mL}\right.$, excess) at $0-5{ }^{\circ} \mathrm{C}$. To this was added a solution of sodium metaperiodate $(3.3 \mathrm{~g}, 15.6 \mathrm{mmol}$ in $\sim 50$

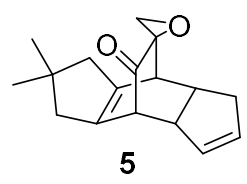
$\mathrm{mL}$ of water) dropwise. After stirring for $3 \mathrm{~h}$ at $0-5{ }^{\circ} \mathrm{C}$, the reaction mixture was brought to ambient temperature and stirred overnight. The reaction mixture was filtered through a Celite bed to remove inorganic salts. The organic layer was separated from the filtrate and the aqueous layer was extracted with ethyl acetate $(4 \times 25 \mathrm{~mL})$. The organic extracts were 
combined and washed with brine $(30 \mathrm{~mL})$ and dried over sodium sulfate. The solvent was removed under vacuum and crude product was chromatographed on silica gel. Elution with petroleum ether-ethyl acetate (93:7) afforded the compound $\mathbf{5}(0.750 \mathrm{~g}, 56 \%)$ as a colourless solid. $\left[R_{\mathrm{f}}=0.7\right.$ petroleum ether/ethyl acetate (80:20)]. mp: $79-81{ }^{\circ} \mathrm{C} . \mathrm{IR}$ (film) $v_{\max }: 2952$, $1734 \mathrm{~cm}^{-1} .{ }^{1} \mathrm{H}$ NMR (400 MHz, $\left.\mathrm{CDCl}_{3}\right): \delta 5.69-5.64(\mathrm{~m}, 1 \mathrm{H}), 5.43-5.38(\mathrm{~m}, 1 \mathrm{H}), 3.41-3.36$ $(\mathrm{m}, 1 \mathrm{H}), 3.32(\mathrm{~d}, J=2.8 \mathrm{~Hz}, 1 \mathrm{H}), 3.10\left(\right.$ Part of an $\mathrm{AB}$ system $\left.J_{\mathrm{AB}}=6.1 \mathrm{~Hz}, 1 \mathrm{H}\right), 3.07-3.00$ (m, 1H), $2.82\left(\right.$ Part of an $\mathrm{AB}$ system $\left.J_{\mathrm{AB}}=6.1 \mathrm{~Hz}, 1 \mathrm{H}\right), 2.63-2.54(\mathrm{~m} .1 \mathrm{H}), 2.52(\mathrm{~d}, \mathrm{~J}=2.8$ $\mathrm{Hz}, 1 \mathrm{H}), 2.36\left(\mathrm{dt}, J_{1}=13.7 \mathrm{~Hz}, J_{2}=2.8 \mathrm{~Hz}, 1 \mathrm{H}\right), 2.28-2.14(\mathrm{~m}, 2 \mathrm{H}), 2.11-2.04(\mathrm{~m}, 1 \mathrm{H})$, 1.98-1.90 (m, 1H), $1.07(\mathrm{~s}, 3 \mathrm{H}), 1.06(\mathrm{~s}, 3 \mathrm{H}) .{ }^{13} \mathrm{C} \mathrm{NMR}\left(100 \mathrm{MHz}, \mathrm{CDCl}_{3}\right): \delta 205,139.7$, $135.4,133.4,129.5,58.9,53.2,52.4,50.8,50.4,49.4,44.4,40.0,38.3,36.9,30.7,29.9$. HRMS (ESI-MS) (m/z): found 279.1352 (M + Na) ${ }^{+}$; calcd for $\mathrm{C}_{17} \mathrm{H}_{20} \mathrm{NaO}_{2}: 279.1356$.

Further elution with petroleum ether-ethyl acetate (85:15) gave the compound $\mathbf{9}$ as a yellow liquid $(0.160 \mathrm{~g}, 16 \%) \quad\left[R_{\mathrm{f}}=0.6\right.$ petroleum ether/ethyl acetate $(80: 20)$, which was identical in all respects to that obtained earlier.

2,2,10-Trimethyl-1,2,3,4,4a,5,7a,8-octahydro-4,8-ethano-s-indacen-9-one (29) and 10(hydroxymethyl)-2,2-dimethyl-1,2,3,4,4a,5,7a,8-octahydro-4,8-ethano-s-indacen-9-one (9)

To a mixture of keto epoxide $\mathbf{5}(1.2 \mathrm{~g}, 4.65 \mathrm{mmol})$ in methanol-water (90 $\mathrm{mL}, 6: 1)$ was added activated zinc ( $3 \mathrm{~g}$, excess) and ammonium chloride (1.23 g, $23.25 \mathrm{mmol})$. The reaction mixture was stirred for $4 \mathrm{~h}$ at room temperature, after which it was filtered through a Celite bed to remove zinc and washed with ethyl acetate $(25 \mathrm{~mL})$. The filtrate was concentrated in vacuum, so as to remove most of the solvent and the residue was diluted with water $(20 \mathrm{~mL})$ and extracted with ethyl acetate $(3 \times 30 \mathrm{~mL})$. The combined organic layer was washed with brine $(20 \mathrm{~mL})$ and dried over anhydrous sodium sulfate. The solvent was removed under vacuum, and the product was chromatographed on silica gel. Elution with petroleum ether-ethyl acetate (95:05) furnished the

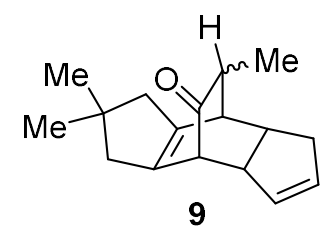


ketone 9 as a colorless liquid $(0.120 \mathrm{~g}, 11 \%),\left[R_{\mathrm{f}}=0.6\right.$ petroleum ether/ethyl acetate $\left.(92: 8)\right]$. IR (film) $v_{\max }: 2952,1721 \mathrm{~cm}^{-1} .{ }^{1} \mathrm{H}$ NMR (400 MHz, $\left.\mathrm{CDCl}_{3}\right): \delta 5.63-5.58(\mathrm{~m}, 1 \mathrm{H}), 5.38-5.34$ $(\mathrm{m}, 1 \mathrm{H}), 3.7(\mathrm{~d}, J=2.6 \mathrm{~Hz}, 1 \mathrm{H}), 2.88-2.82(\mathrm{~m}, 1 \mathrm{H}), 2.68(\mathrm{t}, J=3.0 \mathrm{~Hz}, 1 \mathrm{H}), 2.55-2.46(\mathrm{~m}$, $1 \mathrm{H}), 2.32\left(\mathrm{dt}, J_{1}=16.1 \mathrm{~Hz}, J_{2}=2.2 \mathrm{~Hz}, 1 \mathrm{H}\right), 2.20-2.09(\mathrm{~m}, 2 \mathrm{H}), 2.05-1.98(\mathrm{~m}, 2 \mathrm{H}), 1.94-1.86$ (m, 1H), 1.12 (d, $7.3 \mathrm{~Hz}, 3 \mathrm{H}), 1.04$ (s, 3H), 1.03 (s, 3H). ${ }^{13} \mathrm{C}$ NMR (100 MHz, $\left.\mathrm{CDCl}_{3}\right): \delta$ $215.6,143.1,134.2,132.8,130.2,54.0,50.9,50.1,49.4,43.9,43.7,39.8,38.5,34.7,30.8$, 30.0, 28.7, 14.7. HRMS (ESI) $(\mathrm{m} / \mathrm{z})$ : found $281.1299(\mathrm{M}+\mathrm{K})^{+}$; calcd for $\mathrm{C}_{17} \mathrm{H}_{22} \mathrm{KO}$ : 281.1302 .

Continued elution with petroleum ether-ethyl acetate (70:30) furnished the mixture of keto alcohol 10 as a colorless liquid $(0.800 \mathrm{~g}, 66 \%)\left[R_{\mathrm{f}}=0.3\right.$ petroleum ether/ethyl acetate (80:20)]. IR (film) $v_{\max }: 3421,2925,1721 \mathrm{~cm}^{-1} \cdot{ }^{1} \mathrm{H}$ NMR (400 MHz, $\left.\mathrm{CDCl}_{3}\right): \delta 5.64-5.58(\mathrm{~m}, 1 \mathrm{H}), 5.38-5.35(\mathrm{~m}, 2 \mathrm{H}), 3.85$ $\left(\mathrm{dd}, J_{1}=10.9 \mathrm{~Hz}, J_{2}=8.0 \mathrm{~Hz}, 1 \mathrm{H}\right), 3.66$ and $3.54\left(\mathrm{dd}, J_{1}=7.6 \mathrm{~Hz}, J_{2}=\right.$

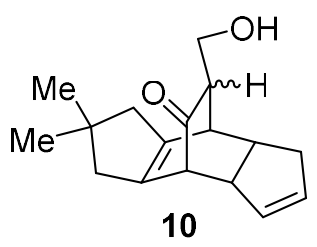
$2.8 \mathrm{~Hz}$, total $1 \mathrm{H}) 3.27-3.324$ and $3.18-3.12(\mathrm{~m}$, total $2 \mathrm{H}), 2.88(\mathrm{t}, J=2.9 \mathrm{~Hz}, 1 \mathrm{H}), 2.80-2.72$ (m, 1H), 2.56-2.46 (m, 1H), 2.38-2.33 and 2.32-2.25 (m, total $1 \mathrm{H}), 2.22-2.12(\mathrm{~m}, 3 \mathrm{H}), 2.18-$ $2.01(\mathrm{~m}, 1 \mathrm{H}), 1.94-1.85(\mathrm{~m}, 1 \mathrm{H}), 1.05(\mathrm{~s}, 6 \mathrm{H}) .{ }^{13} \mathrm{C} \mathrm{NMR}\left(100 \mathrm{MHz}, \mathrm{CDCl}_{3}\right): \delta 215.8,142.7$, $134.4,133.0,132.9,129.9,64.7,62.9,54.3,53.9,52.3,51.7,51.0,50.8,50.6,49.4,49.1$, 48.9, 40.9, 40.5, 40.4, 39.8 38.6, 38.5, 35.7, 30.78, 30.74, 30.3, 30.0, HRMS (ESI) (m/z): found $281.1514(\mathrm{M}+\mathrm{Na})^{+}$; calcd for $\mathrm{C}_{17} \mathrm{H}_{22} \mathrm{NaO}_{2}: 281.1512$.

\section{2,2-Dimethyl-1,2,3,4,4a,5,7a,8-octahydro-4,8-ethano-s-indacen-9-one (4)}

To a solution of the keto alcohol $10(0.750 \mathrm{~g}, 2.90 \mathrm{mmol})$ in acetone $(60 \mathrm{~mL})$ was added a freshly prepared Jones' reagent dropwise at $\sim 5^{\circ} \mathrm{C}$. After the reaction was complete (TLC, $1 \mathrm{~h})$, isopropanol $(10 \mathrm{~mL})$ was added slowly to quenched excess Jones' reagent. Solvent was removed under vacuum

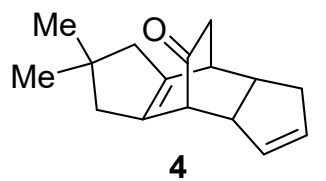
and the residue was diluted with water and extracted with ethyl acetate $(3 \times 30 \mathrm{~mL})$. The combined organic layer was washed with brine $(20 \mathrm{~mL})$ and dried over anhydrous sodium 
sulfate. Removal of the solvent gave a $\beta$-keto acid which was directly subjected to decarboxylation as follows.

The $\beta$-keto acid thus obtained was taken up in THF -water mixture $(70 \mathrm{~mL}, 1: 1)$ and the reaction mixture was refluxed for $15 \mathrm{~h}$ (TLC). THF was removed in vacuum, and the aqueous layer was extracted with ethyl acetate and dried over anhydrous sodium sulfate. The solvent was removed and the residue was chromatographed on silica gel. Elution with petroleum ether-ethyl acetate (90:10) gave the compound 4 as a colorless liquid $(0.400 \mathrm{~g}, 57 \%), \quad\left[R_{\mathrm{f}}=\right.$ 0.5 petroleum ether/ethyl acetate (95:05)]. IR (film) $v_{\max }: 2928,1725 \mathrm{~cm}^{-1} .{ }^{1} \mathrm{H}$ NMR (400 $\left.\mathrm{MHz}, \mathrm{CDCl}_{3}\right): \delta 5.60-5.55(\mathrm{~m}, 1 \mathrm{H}), 5.47-5.43(\mathrm{~m}, 1 \mathrm{H}), 3.26-3.15(\mathrm{~m}, 1 \mathrm{H}), 3.08(\mathrm{~d}, J=$ $2.6 \mathrm{~Hz}, 1 \mathrm{H}), 2.82\left(\mathrm{dd}, J_{1}=5.6 \mathrm{~Hz}, J_{2}=2.6 \mathrm{~Hz}, 1 \mathrm{H}\right), 2.70-2.61(\mathrm{~m}, 1 \mathrm{H}), 2.55-2.46(\mathrm{~m}, 1 \mathrm{H})$, $2.31\left(\mathrm{dt}, J_{1}=15.8 \mathrm{~Hz}, J_{2}=2.4 \mathrm{~Hz}, 1 \mathrm{H}\right), 2.18\left(\mathrm{dt}, J_{1}=15.8 \mathrm{~Hz}, J_{2}=2.4 \mathrm{~Hz}, 1 \mathrm{H}\right), 2.12-2.06(\mathrm{~m}$, 1H), 2.04-1.96 (m, 3H), 1.92-1.84 (m, 1H), $1.02(\mathrm{~s}, 3 \mathrm{H}) .{ }^{13} \mathrm{C}$ NMR $\left(100 \mathrm{MHz}, \mathrm{CDCl}_{3}\right): \delta$ $212.5,141.9,134.3,132.5,130.1,54.0,50.7,49.6,49.3,41.1,40.6,39.9,38.6,37.9,30.8$, 30.0. HRMS (ESI) $(\mathrm{m} / \mathrm{z})$ : found $251.1403(\mathrm{M}+\mathrm{Na})^{+}$; calcd for $\mathrm{C}_{16} \mathrm{H}_{20} \mathrm{NaO}: 251.1406$.

4,4-Dimethyl-4,5,6a,9,9a,9b-hexahydro-1H-cyclobuta[d]-s-indacen-2(3H)-one (11) and 2,2Dimethyl-1,2,3,3b,3c,4,6a,7-octahydro 3a,7ethanocyclopenta[2,3]cyclopropa[1,2a]pentalen9-one (12)

Irradiation of a solution of $\beta$ - $\gamma$ enone4 $(0.100 \mathrm{~g}, 0.41 \mathrm{mmol})$ in degassed acetone $(100 \mathrm{~mL})$ with mercury vapour lamp $(125 \mathrm{~W})$ in a Pyrex

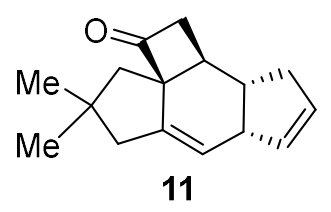
immersion well for $1 \mathrm{~h}$ under nitrogen atmosphere followed by removal of solvent and chromatography [petroleum ether/ethyl acetate (95:5)] gave the 1,3 acyl shift product 11 $(0.030 \mathrm{~g}, 30 \%)$ as a colorless liquid, $\left[R_{\mathrm{f}}=0.6\right.$ petroleum ether/ethyl acetate $\left.(95: 5)\right]$. IR (film) $v_{\max }: 2925,1776 \mathrm{~cm}^{-1} .{ }^{1} \mathrm{H}$ NMR $\left(400 \mathrm{MHz}, \mathrm{CDCl}_{3}\right): \delta 5.90-5.85(\mathrm{~m}, 1 \mathrm{H}), 5.78-5.66(\mathrm{~m}, 1 \mathrm{H})$, $5.22(\mathrm{~s}, 1 \mathrm{H}), 3.13(\mathrm{br} \mathrm{s}, 1 \mathrm{H}), 3.02\left(\mathrm{dd}, J_{1}=17.4 \mathrm{~Hz}, J_{2}=8.7 \mathrm{~Hz}, 1 \mathrm{H}\right), 2.78\left(\mathrm{dd}, J_{1}=17.4 \mathrm{~Hz}\right.$, $\left.J_{2}=7.3 \mathrm{~Hz}, 1 \mathrm{H}\right), 2.58-2.50(\mathrm{~m}, 1 \mathrm{H}), 2.34-2.26(\mathrm{~m}, 1 \mathrm{H}), 2.23-2.17(\mathrm{~m}, 2 \mathrm{H}), 2.06$ (part of an $\mathrm{AB}$ system, $\left.J_{\mathrm{AB}}=13.6 \mathrm{~Hz}, 1 \mathrm{H}\right), 2.03-1.94(\mathrm{~m}, 2 \mathrm{H}), 1.87$ (part of an $\mathrm{AB}$ system, $J_{\mathrm{AB}}=$ 
$13.6 \mathrm{~Hz}, 1 \mathrm{H}), 1.41(\mathrm{~d}, J=13.6 \mathrm{~Hz}, 1 \mathrm{H}), 1.15(\mathrm{~s}, 3 \mathrm{H}), 0.89(\mathrm{~s}, 3 \mathrm{H}) .{ }^{13} \mathrm{C}$ NMR $(100 \mathrm{MHz}$, $\left.\mathrm{CDCl}_{3}\right): \delta 209.5,136.0,134.0,130.3,118.3,68.8,48.5,47.6,47.3,40.7,38.9,36.7,36.2$, 30.5, 30.3, 29.6. HRMS (ESI) $(\mathrm{m} / \mathrm{z})$ : found $251.1405(\mathrm{M}+\mathrm{Na})^{+}$; calcd for $\mathrm{C}_{16} \mathrm{H}_{20} \mathrm{NaO}$ : 251.1406 .

Further elution with petroleum ether/ethyl acetate (94:6)] gave the rearranged product 12 (mixture with unknown hydrocarbon) (0.026 g, $26 \%)\left[R_{\mathrm{f}}=0.4\right.$ petroleum ether/ethyl acetate $\left.(95: 5)\right]$ which was

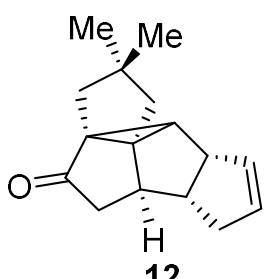
inseparable. This mixture was subjected to hydroxylation as follows.

\section{4,5-Dihydroxy-2,2-dimethyldecahydro-3a,7-ethanocyclopenta[2,3]cyclopropa[1,2- a]pentalen-9-one (13)}

To a solution of the above mixture containing compound $12(0.030 \mathrm{~g}, 0.13 \mathrm{mmol})$ in acetone:water (6:1, $20 \mathrm{~mL})$ were added 4-methylmorpholine N-oxide (0.023 g, $0.197 \mathrm{mmol})$ and osmium tetroxide $(0.005 \mathrm{~g}, 0.002 \mathrm{mmol})$. The reaction mixture was stirred for $24 \mathrm{~h}$ under ambient conditions. After which sodium bisulphite $(0.020 \mathrm{~g}, 0.195 \mathrm{mmol})$ was added. After stirring for further $2 \mathrm{~h}$, the reaction mixture was filtered through a Celite pad. The filtrate was concentrated and the residue was extracted with dichloromethane $(3 \times 10 \mathrm{~mL})$, dried over sodium sulfate, and concentrated in vacuo. The product was purified by column chromatography on silica gel. Elution with petroleum ether-ethyl acetate (70:30) gave the dihydroxylated product $13(0.025 \mathrm{~g}, 72 \%)$ as a thick liquid $\left[R_{\mathrm{f}}=0.4\right.$ petroleum ether/ethyl acetate (70:30)]. IR (film) $v_{\max }: 3424,2951,1708 \mathrm{~cm}^{-1} .{ }^{1} \mathrm{H}$ NMR (400 $\left.\mathrm{MHz}, \mathrm{CDCl}_{3}\right): \delta 2.97\left(\mathrm{dd}, J_{1}=6.1 \mathrm{~Hz}, J_{2}=4.1 \mathrm{~Hz}, 1 \mathrm{H}\right), 2.78($ br s, $1 \mathrm{H}), 2.74\left(\left(\mathrm{dd}, J_{1}=12.6 \mathrm{~Hz}, J_{2}=6.1 \mathrm{~Hz}, 1 \mathrm{H}\right), 2.71-269(\mathrm{~m}, 1 \mathrm{H}), 2.40-\right.$ $2.37(\mathrm{~m}, 1 \mathrm{H}), 2.28\left(\mathrm{dd}, J_{1}=20.3 \mathrm{~Hz}, J_{2}=4.1 \mathrm{~Hz}, 1 \mathrm{H}\right), 2.14-2.08(\mathrm{~m}$,

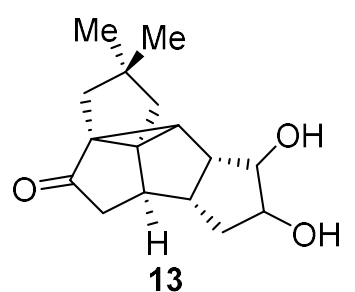
$1 \mathrm{H}), 1.65$ (br s, 1H), 1.61 (part of an $\mathrm{AB}$ system, $J_{\mathrm{AB}}=14.4 \mathrm{~Hz}, 1 \mathrm{H}$ ), 1.50 (part of an $\mathrm{AB}$ system, $\left.J_{\mathrm{AB}}=13.6 \mathrm{~Hz}, 1 \mathrm{H}\right), 1.43\left(\right.$ part of an $\mathrm{AB}$ system, $\left.J_{\mathrm{AB}}=13.6 \mathrm{~Hz}, 1 \mathrm{H}\right), 1.38(\mathrm{~d}, J=10.2$ 
$\mathrm{Hz}, 1 \mathrm{H}$ ), 1.27-1.24 (singlet merged with $\mathrm{m}$, total $4 \mathrm{H}$ ), 1.05 (part of an $\mathrm{AB}$ system, $J_{\mathrm{AB}}=$ 14.4Hz, 1H), $1.01(\mathrm{~s}, 3 \mathrm{H}) .{ }^{13} \mathrm{C} \mathrm{NMR}\left(100 \mathrm{MHz}, \mathrm{CDCl}_{3}\right): \delta 213.6,55.7,52.9,49.2,47.1,46.6$, 46.4, 44.9, 44.3, 42.2, 40.3, 39.9, 38.8, 35.2, 31.3, 29.5. HRMS (ESI) (m/z): found 301.1201 $(\mathrm{M}+\mathrm{K})^{+}$; calcd for $\mathrm{C}_{16} \mathrm{H}_{22} \mathrm{KO}_{3}: 301.1201$.

Direct irradiation of compound 27: formation of 4,4-Dimethyl-4,5,6a,9,9a,9b-hexahydro-1Hcyclobuta[d]-s-indacen-2(3H)-one (11)

A solution of $\beta$ - $\gamma$ enone27 $(0.050 \mathrm{~g}, 0.21 \mathrm{mmol})$ in degassed benzene $(100 \mathrm{~mL})$ was irradiated with a mercury vapour lamp $(125 \mathrm{~W})$ in a Pyrex immersion well for 45 min under nitrogen atmosphere. Benzene was removed under vacuum and the photolysate was chromatographed. Elution with petroleum

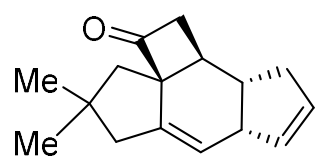

11 ether/ethyl acetate (95:5) gave the 1,3-acyl shift product $11(0.028 \mathrm{~g}, 56 \%)$ as a colorless liquid $\left[R_{\mathrm{f}}=0.5\right.$ petroleum ether/ethyl acetate $\left.(95: 5)\right]$ which was identical in all respects to the compound obtained earlier.

8,8-dimethyl-5-(phenylsulfonyl)-3,3a,4,5,8,9-hexahydroindeno[3a,4-b]furan-2(7H)-one (16)

To a vigorously stirred solution of $15(0.040 \mathrm{~g}, 0.12 \mathrm{mmol})$ in dichloromethane $(20 \mathrm{~mL})$ was added a $0.7 \mathrm{M}$ aqueous solution of sodium bicarbonate $(5 \mathrm{~mL})$ and a solution of 3-chloroperbenzoic acid

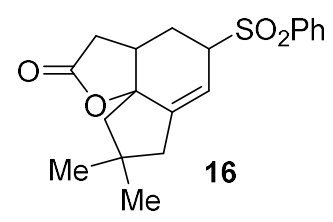
( $0.032 \mathrm{~g}, 0.18 \mathrm{mmol}$ ). The reaction mixture was stirred for $2 \mathrm{~h}$ at room temperature. Then the organic phase was washed with saturated sodium bicarbonate solution $(50 \mathrm{~mL})$ and aqeous layer was extracted with dichloromethane $(3 \times 30 \mathrm{~mL})$. The combined organic layer was washed with brine $(1 \times 20 \mathrm{~mL})$ and dried over anhydrous sodium sulfate. The solvent was evaporated under vacuum and the residue was charged on silica gel coloumn. Elution with petroleum ether/ethyl acetate (60:40)] gave the rearranged product $\mathbf{2 0}(0.024 \mathrm{~g}, 57 \%)$ as a colorless solid, mp. $150-152{ }^{\circ} \mathrm{C}, R_{\mathrm{f}}=0.4$ [petroleum ether/ethyl acetate (70:30)]. (IR (film) $\nu_{\max }: 2952,1761 \mathrm{~cm}^{-1} .{ }^{1} \mathrm{H}$ NMR (400 MHz, $\left.\mathrm{CDCl}_{3}\right): \delta$ 7.89-7.86 (m, 2H), 7.70 (merged dd, 
$\left.J_{1}=J_{2}=7.4 \mathrm{~Hz}, 1 \mathrm{H}\right), 7.61\left(\right.$ merged dd, $\left.J_{1}=J_{2}=7.4 \mathrm{~Hz}, 2 \mathrm{H}\right), 5.62-5.58($ br s, $1 \mathrm{H}), 3.78-3.73$ (br s, $1 \mathrm{H}), 2.82\left(\mathrm{dd}, J_{1}=17.3 \mathrm{~Hz}, J_{2}=7.4 \mathrm{~Hz}, 1 \mathrm{H}\right), 2.70-2.65(\mathrm{~m}, 1 \mathrm{H}), 2.57\left(\mathrm{dt}, J_{1}=15.0 \mathrm{~Hz}\right.$, $\left.J_{2}=2.8 \mathrm{~Hz}, 1 \mathrm{H}\right), 2.30\left(\mathrm{dd}, J_{1}=15.0 \mathrm{~Hz}, J_{2}=4.9 \mathrm{~Hz}, 1 \mathrm{H}\right), 2.20\left(\mathrm{dd}, J_{1}=17.3 \mathrm{~Hz}, J_{2}=8.4 \mathrm{~Hz}\right.$ $2 \mathrm{H}), 1.98(\mathrm{~d}, J=4.2 \mathrm{~Hz}, 1 \mathrm{H}), 1.71-1.67(\mathrm{~m}, 1 \mathrm{H}), 1.59\left(\right.$ merged dd, $\left.J_{1}=J_{2}=8.4 \mathrm{~Hz}, 1 \mathrm{H}\right), 1.22$ (s, 3H), $1.05(\mathrm{~s}, 3 \mathrm{H}) .{ }^{13} \mathrm{C}$ NMR (100 MHz, $\left.\mathrm{CDCl}_{3}\right): \delta 175.2,148.1,138.0,134.2,129.6$, 129.0, 114.2, 89.2, 60.6, 52.0, 46.6, 36.6, 36.5, 34.5, 31.1, 30.9, 25.6. HRMS (ESI) (m/z): found $369.1133(\mathrm{M}+\mathrm{Na})^{+}$; calcd for $\mathrm{C}_{19} \mathrm{H}_{22} \mathrm{NaO}_{4} \mathrm{~S}: 301.1201$.

\section{Acknowledgements}

The authors acknowledge the financial support through Researchers Supporting Project number (RSP-2020/147), King Saud University, Riyadh, Saudi Arabia.

\section{Conflict of interest}

There are no conflicts to declare. 


\section{References}

1. (a) Paquette, L. A.; Doherty, A.M. Recent Synthetic Developments in Polyquinane Chemistry; Springer-verlag: New York,1987 and references therein. (b) Mehta, G.; Srikrishna, A. Chem. Rev. 1997, 97, 671 and references therein. (c) Singh, V.; Thomas, B.(d) Tetrahedron1998, 54, 3647.Lee, H. -Y. Acc. Chem. Res. 2015, 48, 2308.

2. Kupka, J.; Anke, T.; Oberwinkler, F.; Schramm, G.; Steglich, W. J. Antibiot. 1979, 32, 130.

3. (a) Li, Y.-Y.; Shen, Y.-M. Helv. Chim. Acta 2010, 93,2151. (b)Anke, T.; Heim, J.; Knoch, F.; Mocek, U.; Steffan, B.; Steglich, W. Angew. Chem., Int. Ed. Engl. 1985, 24, 709.

4. King, T.; Farrell, K.; Halsall, T.; Thaller, V. J. Chem. Soc., Chem. Commun.1977, 20, 727.

5. (a) Schwartz, C. E.; Curran, D. P. J. Am. Chem. Soc. 1990, 112, 9272; (b) Mehta, G.;Rao, K. S.; Reddy, M. S. J. Chem. Soc. Perkin I 1991, 693 and references therein;(c) Chen, P.; Carroll, P. J.; Sieburth, S. M. Org. Lett. 2010, 12, 4510; (d) Srikrishna,A.; Gowri, V. Synlett2011, 2652; (e) Srikrishna, A.; Gowri, V. Tetrahedron2012, 68, 3046; (f) Piers, E.; Renaud, J. J. Org. Chem. 1993, 58, 11; (g)Piers, E.; Renaud, J.; Rettig, S. J. Synthesis 1998, 590; (h) Wender, P. A.; Dore, T.M. Tetrahedron Lett. 1998, 39, 8589; (i) Kang, T.; Song, S. B.; Kim, W.-Y.; Kim, B.G.; Lee, H.-Y. J. Am. Chem. Soc. 2014, 136, 10274.

6. Kang, T.; Song, S. B.; Lee, H. Y. J. Am. Chem. Soc. 2014, 136, 10274.

7. (a) Sahu, R.; Singh, V. J. Org. Chem.2017, 82, 6268; (b) Behera, T. K.; Jarhad, D. B.; Mobin, S. M.; Singh, V. Tetrahedron.2016, 72, 5377; (c) Sahu, R.; Singh, V. Synthesis.2019, 51, 1633; (d) Singh, V.; Sahu, B. C.; Bansal, V.; Mobin, S. M. Org. Biomol. Chem. 2010, 8, 4472; (f) Singh, V. Synlett. 2013, 2641.

8. Sahu, R.; Singh, V. Tetrahedron.2017, 82, 6515.

9. R. K. Mohapatra, P. K. Das, V. Kandi, Diabetes \& Metabolic Syndrome: Clinical Research \& Reviews, 2020, 14, 1593-1594. 
10. R. K. Mohapatra, L. Pintilie, V. Kandi, et al., Chemical Biology \& Drug Design, 2020. https://doi.org/10.1111/cbdd.13761.

11. CLC Drug Discovery Workbench, available from http://www.clcbio.com.

12. Yu, E.W., Aires, J.R., McDermott, G., Nikaido, H.,A Periplasmic Drug-Binding Site of the AcrB Multidrug Efflux Pump: a Crystallographic and Site-Directed Mutagenesis Study, J. Bacteriol.,2005, 187, p.6804-6815.

13. Mesecar, A.D., A taxonomically-driven approach to development of potent, broad-spectrum inhibitors of coronavirus main protease including SARS-CoV-2 (COVID-19), 2020, DOI: $10.2210 / \mathrm{pdb} 6 \mathrm{~W} 63 / \mathrm{pdb}$, to be published.

14. Laponogov, I., Veselkov, D.A., Pan, X.-S., Selvarajah, J., Crevel, I.M.-T., Fisher, L.M., Sanderson, M.R., Quinolone (Moxifloxacin)-DNA cleavage complex of gyrase from S. pneumoniae, 2020,DOI: 10.2210/pdb4z2c/pdb, to be published.

15. Shiau, A.K., Barstad, D., Loria, P.M., Cheng, L., Kushner, P.J., Agard, D.A., Greene, G.L., The Structural Basis of Estrogen Receptor/Coactivator Recognition and the Antagonism of This Interaction by Tamoxifen, Cell, 1998,95, p.927-937.

16. Strushkevich, N.,Sergey A.Usanov, S.A.,Hee-Won Park, H-W., Structural Basis of Human CYP51 Inhibition by Antifungal Azoles,J. Mol. Biol., 2010, 397(4), p.1067-1078, https://doi.org/10.1016/j.jmb.2010.01.075.

17. Kurumbail, R.G., Stevens, A.M., Gierse, J.K., McDonald, J.J., Stegeman, R.A., Pak, J.Y., Gildehaus, D., Miyashiro, J.M., Penning, T.D., Seibert, K., Isakson, P.C., Stallings, W.C., Structural basis for selective inhibition of cyclooxygenase-2 by anti-inflammatory agents, Nature, 1996, 384, p. 644-648.

18. Lipinski C.A., Lombardo F., Dominy B.W. and Feeney P.J., Advanced Drug Delivery Reviews.2001,46, p.3-26. 